Phinisi Integration Review
Vol. 3, No.2, Agustus 2020 Hal 223-236
Website: http://ojs.unm.ac.id/pir
p-ISSN: 2614-2325 dan e-ISSN: 2614-2317
DOI: https://doi.org/10.26858/v3i2.14885

\title{
Pengaruh Model Pembelajaran Team Assisted Individualization (TAI) dan Pengelolaan Kelas Terhadap Motivasi Belajar PPKn Peserta Didik
}

\author{
Mufti Syaifuddin $^{1}$ Imam Suyitno $^{2}$ Mustari $^{3}$ \\ ${ }^{123} \mathrm{Ilmu}$ Pendidikan Sosial,Universitas Negeri Makassar, Indonesia \\ Email: ${ }^{1}$ muftisyaifuddin0@gmail.com
}

\begin{abstract}
Abstrak. Pengaruh Model Pembelajaran Team Assisted Individualization (TAI) dan Pengelolaan Kelas Terhadap Motivasi Belajar PPKn Peserta Didik di SMP Negeri 8 Makassar.Penelitian ini bertujuan untuk mengetahui; (i) apakah terdapat pengaruh positif dan signifikan model Team Assisted Individualization (TAI) dan pengelolaan kelas terhadap motivasi belajar PPKn peserta didik di SMP Negeri 8 Makassar, (ii) apakah terdapat pengaruh positif dan signifikan model Team Assisted Individualization (TAI) terhadap motivasi belajar PPKn peserta didik di SMP Negeri 8 Makassar, (iii) apakah terdapat pengaruh positif dan signifikan pengelolaan kelas terhadap motivasi belajar PPKn peserta didik di SMP Negeri 8 Makassar. Jenis penelitian yang digunakan dalam penelitian ini adalah kuantitatif dengan metode survey.Populasi dalam penelitian ini adalah seluruh peserta didik kelas VIII SMP Negeri 8 Makassar yang berjumlah 440.Teknik pengambilan sampel denganSimple Random Sampling dengan jumlah sampel 195. Teknik pengumpulan data yang melalui angket, dan dokumentasi. Hasil penelitian ini menunjukkan bahwa (i) terdapat pengaruh yang positif dan signifikan model Team Assisted ndividualization (TAI) dan pengelolaan kelas terhadap motivasi belajar PPKn peserta didik di SMP Negeri 8 Makassar. Ditunjukkan dengan nilai Fhitung sebesar 108,104 > Ftabel 3,04. Sementara tingkat signifikansi $0,000<0,05$ dan secara simultan ada 53\% kontribusi model Team Assisted Individualization (TAI) dan pengelolaan kelas terhadap motivasi belajar PPKn peserta didik di SMP Negeri 8 Makassar. (ii) terdapat pengaruh yang positif dan signifikan antara model pembelajaran Team Assisted Individualization (TAI) terhadap motivasi belajar PPKn peserta didik di SMP Negeri 8 Makassar. Ditunjukkan dengan nilai thitung $12,749>$ ttabel 1,645 dengan signifikansi $0,000<0,05$. (iii) terdapat pengaruh yang positif dan signifikan antara pengelolaan kelas terhadap motivasi belajar PPKn peserta didik di SMP Negeri 8 Makassar. Ditunjukkan nilai thitung 11, $365>$ ttabel 1,645 dengan signifikansi $0,000<0,05$.
\end{abstract}

Kata Kunci: Model TAI; pengelolaan kelas; motivasi belajar.

Abstract. This study aims to determine; (i) whether there is a positive and significant influence on the Team Assisted Individualization (TAI) model and classroom management on the learning motivation of students PPKn at SMP Negeri 8 Makassar, (ii) whether there is a positive and significant effect of the Team Assisted Individualization (TAI) model on the learning motivation of students PPKn at SMP Negeri 8 Makassar, (iii) whether there is a positive and significant influence of classroom management on the learning motivation of PPKn learners at SMP Negeri 8 Makassar. This type of research used in this research is quantitative with survey methods. The population in this study were all students of class VIII SMP Negeri 8 Makassar, amounting to 440. The sampling technique was Simple Random Sampling technique with a total sample of 195. Data collection techniques used were collected through questionnaire, and documentation. The results of this study indicate that (i) there is a positive and significant influence on the Team Assisted Individualization (TAI) model and classroom management on the learning motivation of students PPKn at 
SMP Negeri 8 Makassar. Shown with the Fcount value of 108.104 > Ftable 3.04. While the significance level is $0,000<0.05$ and simultaneously there are $53 \%$ of the contribution of the Team Assisted Individualization (TAI) model and classroom management to the learning motivation of students PPKn at SMP Negeri 8 Makassar. (ii) there is a positive and significant influence between the Team Assisted Individualization (TAI) learning model on the learning motivation of students PPKn at SMP Negeri 8 Makassar. Shown by the tcount $12,749>$ ttable 1.645 with a significance of $0.000<0.05$. and (iii) there is a positive and significant effect between classroom management on students' learning motivation of PPKn at SMP Negeri 8 Makassar. Shown tcount 11, $365>$ ttable 1.645 with a significance of $0,000<0.05$

Keywords: TAI model; classroom management; learning motivation.

Ini adalah artikel dengan akses terbuka dibawah licenci CC BY-NC-4.0

(https://creativecommons.org/licenses/by-nc/4.0/).

\section{PENDAHULUAN}

Pendidikan adalah usaha sadar untuk menumbuh kembangkan potensi sumber daya manusia (SDM) melalui kegiatan pengajaran.Kegiatan pengajaran tersebut diselenggarakan pada semua satuan dan jenjang pendidikan yang wajib belajar 9 tahun, pendidikan menengah, dan perguruan tinggi.Seperti yang telah diamanatkan dalam pembukaan UUD RI Tahun 1945 alinea keempat, yaitu mencerdaskan kehidupan bangsa. Amanat tersebut dipertegas dalam UUD 1945 Pasal 31 Ayat 3, yakni pemerintah mengusahakan dan menyelenggarakan satu sistem pendidikan nasional, yang meningkatkan keimanan dan ketakwaan serta akhlak mulia dalam rangka mencerdaskan kehidupan bangsa, yang diatur dengan undang-undang.

Berdasarkan Undang-undang Sistem Pendidikan Nasional Nomor 20 Tahun 2003 pasal 37 ayat (1) menjelaskan bahwa pendidikan kewarganegaraan dimaksudkan untuk membentuk peserta didik menjadi manusia yang memiliki rasa kebangsaan dan cinta tanah air. Usaha yang dilakukan untuk mencerdaskan bangsa adalah dengan mendirikan lembaga pendidikan.

Pembelajaran PPKn sangat dipengaruhi oleh pengelolaan kelas dan motivasi belajar peserta didik. Pengelolaan kelas harus maksimal sehingga kegiatan-kegiatan untuk menciptakan kondisi belajar yang optimal bagi peserta didik Pengelolaan kelas adalah usaha yang dilakukan oleh guru untuk mengatur kegiatan pembelajaran, yang meliputi penyiapan bahan ajar, penyediaan sarana dan media pembelajaran, dan menciptkan suasan pembelajaran yang kondusif sehingga membangkitkan motivasi belajar peserta didik. Motivasi belajar adalah serangkaian usaha untuk menyediakan kondisi-kondisi tertentu, sehingga seseorang mau dan ingin melakukan sesuatu dan bila tidak suka maka akan berusaha untuk meniadakan atau mengelakkan perasaan tidak suka itu. Jadi motivasi dapat dirangsang oleh faktor dari luar, tetapi motivasi itu tumbuh didalam diri seseorang (Emda, 2017).Oleh karena itu motivasi belajar menjadi salah satu kunci keberhasilan dalam mencapai tujuan pembelajaran.Dalam upaya peningkatan kualitas pembelajaran, berbagai upaya dilakukan, salah satunya yakni dengan peningkatan pengelolaan kelas dan motivasi belajar sehingga peserta didik termotivasi dalam belajar. Dalam hal belajar peserta didik akan berhasil jika dalam dirinya sendiri ada kemauan untuk belajar dan keinginan atau dorongan untuk belajar, karena dengan peningkatan motivasi belajar maka peserta didik akan tergerak, terarahkan sikap dan perilaku peserta didik dalam belajar.

Peningkatan motivasi memerlukan proses pembelajaran yang dapat membangkitkan gairah belajar, salah satunya dengan menggunakan model pembelajaran yang menarik bagi peserta didik. Salah satu model pembelajaran yang dapat meningkatkan motivasi belajar peserta didik yaitu model pembelajaran kooperatif tipe Team Assisted Individualizatioan (TAI) yang dikembangkan oleh Robert E Slavin.

Berdasarkan observasi awal yang telah dilakukan pada tanggal 5, 6 dan 9 September 2019 di SMP Negeri 8 Makassar, menemukan bahwa dalam proses pembelajaran dikelas guru 


\section{Syaifuddin, dkk. Pengaruh Model Pembelajaran Team Assisted Individualization ...}

mengalami permasalahan dalam menerapkan model yang digunakan pada saat pembelajaran, dan guru kesulitan melaksanakan pembelajaran partisipatif terhadap siswa, serta masih kurangnya aktivitas pengelolaan kelas yang dilakukan oleh guru. Kondisi seperti itu akan berdampak pada motivasi belajar peserta didik. Realita dilapangan menunjukkan motivasi belajar peserta didik di SMP Negeri 8 Kota Makassar rendah, khususnya pada mata pelajaran PPKn. Dari hasil wawancara dan observasi menunjukkan bahwa rendahnya motivasi belajar PPKn peserta didik disebabkan oleh beberapa faktor seperti : 1) Guru lebih dominan dalam proses pembelajaran di kelas; 2) siswa kurang aktif dalam proses pembelajaran; seperti jarang bertanya maupun mengemukakan pendapatnya karena terbiasa hanya mendengarkan penjelasan guru, sehingga pelaksanaan tutor sebaya (peer tutoring) tidak berjalan; 3) siswa kurang berani untuk menanggapi atau mengajukan pertanyaan dari hasil presentasi temanya meskipun guru sudah memberikan kesempatan; 4) penggunaan model pembelajaran yang digunakan oleh guru yang tidak membangkitkan motivasi belajar peserta didik sehingga peserta didik tidak tertarik dengan pembelajaran di kelas; serta 5) masih kurangnya aktivitas pengelolaan kelas yang dilakukan oleh guru seperti pengelolaan meja dan kursi yang belum optimal dan alat-alat pembelajaran yang belum terpenuhi.

Olehnya itu dalam hal ini, peneliti mencoba mencari solusi dengan teman sejawat dengan melihat teori-teori yang mendukung untuk memecahkan permasalahan tersebut. Solusi yang didapat dengan menerapkan alternatif tindakan untuk meningkatkan kualitas pembelajaran, dengan membangkitkan motivasi belajar yang dapat mendorong keterlibatan peserta didik dalam pembelajaran dan meningkatkan kreativitas serta keterampilan guru, dimana salah satu model pembelajaran yang dianggap penting dalam meningkatkan efektivitas motivasi belajar PPKn dengan menerapkan model pembelajaran Team Assisted Individualization (TAI) dan pengelolaan kelas.

Diharapkan setelah menerapkan model pembelajaran Team Assisted Individualization (TAI) dan strategi pengelolaan kelas diharapkan motivasi belajar peserta didik dapat meningkat. Melalui model Team Assisted Individualization (TAI), peserta didik mencoba untuk menggali kemampuannya sendiri melalui pengalaman yang mereka miliki, kemudian bekerja sama dan mendiskusikannya, sehingga secara bersama- sama siswa dapat mengeksplorasi perasaan, sikap, nilai, dalam proses pembelajaran. Melalui model Team Assisted Individualization (TAI) juga membantu meningkatkan pemecahan masalah peserta didik. Pada model Team Assisted Individualization (TAI) peserta didik mendapatkan penghargaan atas usaha mereka. Team Assisted Individualization (TAI) juga melatih peserta didik untuk bekerja secara kelompok, melatih keharmonisan dalam hidup bersama atas dasar saling menghargai.

\section{TINJAUAN PUSTAKA}

1. Model Pembelajaran Team Assisted Individualization (TAI)

a) Pengertian model Team Assisted Individualization.

Kegiatan pembelajaran di sekolah menunjukkan bahwa banyak model pembelajaran dikembangkan, namun masih jarang digunakan dalam proses pembelajaran. Adanya kecenderungan untuk melaksanakan pembelajaran yang berpusat pada guru masih lebih dominan dilakukan daripada pembelajaran yang berpusat pada siswa. Hal ini disebabkan karena terlalu banyak hal yang sebelum pembelajaran di laksanakan, ataupun kurangnya pengetahuan guru mengenai model-model pembelajaran yang tepat untuk digunakan.Oleh karena itu, dalam memilih suatu model pembelajaran seyogiyanya guru harus memperhatikan kondisi siswa, materi bahan ajar, fasilitas media yang tersedia, dan kondisi guru itu sendiri. "Dasar pemikiran untuk, mengadaptasi pengajaran terhadap perbedaan individual berkaitan dengan kemampuan siswa, maupun pencapaian prestasi siswa" Slavin (2005: 187).

Shoimin (2014) mengungkapkan bahwa Team Asissted Individualization (TAI) memiliki dasar pemikiran yaitu untuk mengadapsi pembelajaran terhadap perbedaan individual berkaitan dengan kemampuan maupun pencapaian prestasi siswa Model ini termasuk dalam pembelajaran kooperatif.

b) Langkah-langka model Team Assisted

\section{Individualization}

Menurut Shoimin (2014) langkahlangkah model pembelajaran tipe Team Asissted Individualization (TAI) terdapat 7 tahapan dalam pelaksanaannya, yaitu: "a) Team; b) Teaching Group; c) Student Creative; d) Team Study; e) Test; f) Team Score and Team Recognition; g) Whole-Class Units." 
c) Kelebihan dan Kekurangan model Team Assisted Individualization

Adapun kelebihan dari model pembelajaran Team Assisted Individualization TAI adalah:1) Siswa yang lemah dapat terbantu dalam menyelesaikan masalahnya; 2) Siswa yang pandai dapat mengembangkan kemampuan dan keterampilnnya; 3) Adanya tanggung jawab dalam kelompok dalam menyelesaikan masalahnya; 4) Mengurangi kecemasan; 5) Menghilangkan perasaan "terisolasi" dan panik,; 6) Menggantikan bentuk persaingan dengan saling kerja sama; 7) Melibatkan siswa untuk aktif dalam proses belajar; 7) Mereka dapat berdiskusi, berdebat, atau menyampaiakan gagasan konsep dan keahlian sampai benar-benar memahaminya; 8) Memiliki rasa peduli dan tanggung jawab terhadap teman yang lain dalam proses belajarnya;9) Mereka dapat belajar saling menghargai perbedaan etnik dan perbedaan tingkat kemampuannya. Sedangkan adapun dari model pembelajaran Team Assisted Individualization TAI adalah: 1) Tidak ada persaingan antarkelompok; 2) Siswa yang lemah dimungkinkan menggantungkan pada siswa yang pandai; 3) Terhambatnya cara berfikir siswa yang mempunyai kemampuan lebih terhadap siswa yang masih kurang; 4) Memerlukan periode lama; 5) Sesuatu yang harus dipelajari dan dipahami belum seluruhnya dicapai siswa; 6) Bila kerja sama tidak dapat dilaksanakan dengan baik, yang akan bekerja hanyalah beberapa murid yang pintar dan aktif; 7) Siswa yang pintar akan merasa keberatan karena nilai yang diperoleh ditentukan oleh prestasi atau pencapaian kelompok.

2. Pengelolaan Kelas

a) Pengertian Pengelolaan Kelas

Pada hakikatnya, kegiatan guru dalam di dalam kelas meliputi dua hal pokok, yakni mengajar dan mengelola kelas.Kegiatan mengajar dikamsudkan sebagai upaya menggiatkan siswa untuk mencapai tujuan pembelajaran.

Menurut Djabidi (2016: 35) mengatakan bahwa: "Kegiatan mengelola kelas dimaksudkan sebagai proses menciptkan dan mempertahankan susasana kelas agar kegiatan mengajar dapat berlangsung secara efektif dan efisien seperti melalui pemberian pengajaran dengan segera, pengembangan hubungan yang baik antara guru dan siswa serta pengembangan hubungan yang baik antara guru dan siswa serta pengembangan aturan permainan dalam kegiatan kelompok..
Banyak guru mengajar terkadang tidak memahami tentang manajemen dalam kegiatan belajar mengajar dikelas dalam minsetnya hanya berkuat pada cara yang tepat untuk menyampaiakan materi sebagai tanggung jawab moral dalam mencerdaskan siswanya".

Lebih lanjut menurut Sedangkan menurut Djabidi (2016: 42) adapun tujuan secara umum dari pengelolaan kelas adalah sebagai berikut:" 1) Agar pengajaran dapat dilakukan secara maksimal, sehingga tujuan pengajaran dapat dicapai secara efektif dan efisien; 2) Untuk memberi kemudahan dalam usaha memantau kemajuan siswa dalam pelajarannya; 3) Untuk memberi kemudahan dalam mengangkat masalah-masalah penting untuk dibicarakan dikelas demi perbaikan pengajaran pada masa mendatang.

b) Strategi Pengelolan Kelas

Menurut Munandar 1992 (dalam Djabidi (2016) strategi-strategi pengelolaan kelas yang sebagai berikut: “1) Memulai pelajaran tepat waktu; 2) Menata tempat duduk yang tepat dengan cara menyelaraskan antar format dan tujuan pengajaran; 3) Mengatasi gangguan dari luar kelas; 4) Menetapkan aturan dan prosedur dengan jeas dan dapat dilaksanakan dengan konsisten, Peralihan yang mulus antarsegmen pelajaran; 5) Menegur siswa yang berbicara pada saat proses belajar mengajar berlangsung; 6) Pemberian pekerjaan rumah; 7) Mempertahankan momentum selama pelajaran; 8) Downtime, kelebihan waktu yang dimiliki siswa pada saat melakukan tugas-tugas dalam proses belajar mengajar; 9) Mengakhiri pelajaran.

c) Faktor-faktor yang Mempengaruhi

\section{Pengelolaan Kelas}

Faktor pendukung dan penghambat dalam pengelolaan kelas dalam meningkatkan belajar siswa adalah faktor Intern dan faktor Ekstern yang didalamnya mencakup masalah tenaga pendidik, peserta didik, fasilitas (lingkungan fisik), lingkungan masyarakat.Faktor Interen siswa berhubungan dengan emosi, pikiran, perilaku, dan kepribadian siswa.Sedangkan faktor Ekstern berhubungan dengan lingkungan tempat belajar, penempatan siswa, pengelompokkan siswa, dan jumlah siswa.

\section{Motivasi Belajar}

a) Pengertian Motivasi Belajar

Menurut Dimyanti dan Mudjino (2006: 80) "motivasi belajar merupakan kekuatan mental yang mendorong terjadinya proses 


\section{Syaifuddin, dkk. Pengaruh Model Pembelajaran Team Assisted Individualization ...}

belajar". Menurut Suprijono (2009) motivasi belajar adalah proses yang memberi semangat, arah, dan kegigihan perilaku. Artinya perilaku yang termotivasi adalah perilaku yang penuh energy, terarah dan bertahan lama.Sedangkan menurut Emda (2017) motivasi belajar adalah serangkaian usaha untuk menyediakan kondisikondisi tertentu, sehingga seseorang mau dan ingin melakukan sesuatu dan bila tidak suka maka akan berusaha untuk meniadakan atau mengelakkan perasaan tidak suka itu.

b) Faktor-faktor yang mempengaruhi Motivasi Belajar

Menurut Yusuf (2009) mengemukakan bahwa motivasi belajar dapat timbul karena faktor internal dan eksternal. Motivasi memiliki beberapa jenis dan macamnya, motivasi belajar menurut Sani (2013: 49) dalam bukunya yang berjudul inovasi pembelajaran mengkategorikan dua jenis motivasi belajar, yaitu: 1) Motivasi Ekstrinsik, yakni motivasi melakukan sesuatu karena pengaruh eksternal; Motivasi ekstrinsik muncul akibat insentif eksternal atau pengaruh dari luar peserta didik, misalnya: tuntutan, imbalan, dan hukuman; 2) Motivasi Instrinsik, yakni motivasi internal dari dalam diri untuk melakukan sesuatu, misalnya peserta didik mempelajari mata pelajaran karena dia menyenangi pelajaran tersebut.

c) Fungsi Motivasi Belajar

Menurut Sardiman (2014) mengemukakan tiga fungsi motivasi yaitu sebagai berikut: 1) Mendorong manusia untuk berbuat, jadi sebagai penggerak atau motor yang melepaskan energy. Motivasi dalam hal ini merupakan motor penggerak dari setiap kegiatan yang akandikerjakan; 2) Menentukan arah perbuatan, yakni kearah tujuan yang hendak dicapai. Dengan demikian motivasi dapat memberikan arah dan kegiatan yang harus dikerjakan sesuai dengan rumusan tujuannya; 3) Menyeleksi perbuatan, yakni menentukan perbuatanperbuatan apa yang harus dikerjakan yang serasi guna mencapai tujuan, dengan menyisihkan perbuatan-perbuatan yang tidak bermanfaat bagi tujuan tersebut.

d) Upaya Meningkatkan Motivasi Belajar

Adapun bentuk-bentuk / upaya-upaya yang dapat meningkatkan motivasi belajar menurut Syardiansyah (2016) adalah sebagai berikut: 1) Memberi angka; 2) Hadiah; 3) Saingan kompetensi; 4)Ego-involve; 5) Memberi ulangan; 6) Mengetahui hasil; 7) Pujian; 8)
Hukuman; 9) Hasrat untuk belajar; 10) Tujuan yang diakui; 11) Minat.

\section{e) Ciri-ciri Motivasi Belajar}

Dari berbagai teori motivasi yang berkembang, Keller dalam Wena (2009: 33) telah menyusun pula seperangkat prinsip-prinsip motivasi yang dapat di terapkan dalam proses pembelajaran, yang disebut $A R C S$ model. Model motivasi ini dikembangkan berdasarkan teori nilai harapan (expectancy value theory) yang mengandung dua komponen yaitu nilai (value) dari tujuan yang akan dicapai dan harapan (expectancy) agar berhasil mencapai tujuan itu.

Selanjutnya dari dua komponen tersebut oleh Keller dikembangkan menjadi empat komponen. Keempat komponen itu adalah: 1) Attentioan (perhatian) yaitu dorongan rasa ingin tahu; 2) Relevance (relevansi) yaitu adanya hubungan yang ditunjukkan antara materi pembelajaran, kebutuhan dan kondisi peserta didik; 3) Confidence (kepercayaan diri) yaitu merasa diri kompeten atau mampu, merupakan potensi untuk dapat berinteraksi dengan lingkungan; dan 4) Statisfaction (kepuasan) yaitu keberhasilan dalam mencapai suatu tujuan yang akan menghasilkan kepuasan.

4. Pendidikan Pancasila dan Kewarganegaraan

\section{a) Pengertian PPKn}

Mata pelajaran Pendidikan Pancasila dan Kewarganegaraan (PPKn) merupakan mata pelajaran wajib dalam kurikulum 2013. Sutrisno (2017: 167) menyatakan bahwa "Pendidikan Pancasila dan Kewarganegaraan (PPKn) merupakan pendidikan yang memuat nilai-nilai karakter kebangsaan". Sedangkan menurut Bakry (2012) Pendidikan Pancasila dan Kewarganegaraan adalah usaha sadar untuk menyiapkan peserta didik dalam mengembangkan kecintaan, kesetiaan, keberanian untuk berkorban membela bangsa dan tanah air Indonesia.

b) Tujuan PPKn

Sutrisno (2017: 178) menyatakan bahwa "Pendidikan Pancasila dan Kewarganegaraan (PPKn) merupakan pendidikan yang berfungsi untuk membangun kesadaran warga negara dalam menjalankan hak dan kewajiban sebagai warga negara dalam upaya membentuk identitas terhadap warga Negara".

Sejalan dengan tujuan PPKn tersebut, tujuan PPKn menurut Bakri (2012) adalah untuk memupuk kesadaran kewajiban asasi manusia dalam usaha pembelaan negara 
dengan perilaku cinta tanah air dalam usaha pertahanan keamanan negara dengan kesadaran berbangsa dan bernegara yang berpola pikir komprehensip integral.

c) Ruang Lingkup PPKn

Menurut Faturrohman \& Wuryandi (2011) dalam BSNP, ruang lingkup mata pelajaran Pendidikan Kewarganegaraan meliputi aspekaspek sebagai berikut:1) Persatuan dan Kesatuan bangsa; 2) Norma; hukum, dan peraturan; 3) Hak asasi manusia, 4) Kebutuhan warga negara; 5) Konstitusi Negara; 6) Kekuasaan dan politik; 7) Pancasila;dan8) Globalisasi.

\section{METODE}

Penelitian ini termasuk penelitian kuantitatif yang bersifat deskriptif korelasional dan tergolong ke dalam jenis penelitian survey, Penelitian survei dilakukan untuk mengambil suatu generalisasi dari pengamatan yang tidak mendalam, metode ini tidak memerlukan kelompok kontrol, namun generalisasi yang dilakukan bisa lebih akurat jika menggunakan sampel yang representative.

Definisi operasional digunakan untuk menyamakan persepsi antara penulis dengan pembaca terhadap variabel yang digunakan.Variabel dalam penelitian ini terdiri dari model pembelajaran Team Assisted Individualization (X1) dan pengelolaan kelas (X2) sebagai variabel terikat.Motivasi belajar sebagai variabel bebas. Definisis kedua variabel tersebut adalah:

Model Team Assisted Individualization (X2) dengan indikatornya adalah: 1) Team;2) Teaching Group; 3) Student Creative;4) Team Study; 5) Test;6) Team Score and Team Recognition;7) Whole Class Unit. Pengelolaan kelas (X2) dengan indikatornya adalah: 1) manajemen kelas; 2) manajemen siswa; 3) manajemen kegiatan pembelajaran 4) manajemen isi (materi pembelajaran); 5) manajemen sumber belajar. Motivasi belajar (Y) dengan indikatornya adalah: 1) adanya perhatian dan semangat serta ketertarikan dalam mengikuti kegiatan pembelajaran; 2) adanya kemandirian serta kemampuan menghadapi tantangan untuk menyelesaikan tugas; 3) rasa ingin tahu dan percaya diri dalam menyelesaikan tugas; 4) adanya perasaan puas atas pekerjaan dan penghargaan.

Penelitian ini ingin mengkaji pengaruh model Team Assisted Individualization dan pengelolaan kelas terhadap motivasi belajar PPKn peserta didik di SMP Negeri 8 Makassar. Adapun rancangan penelitiannya dapat digambarkan sebagai berikut:

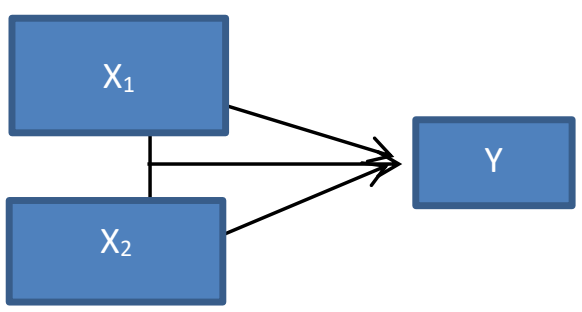

Keterangan:

$\mathrm{X}_{1}$ :Model Team Assisted Individualization

$\mathrm{X}_{2}$ :Pengelolaan kelas

$\mathrm{Y}$ : Motivasi belajar

$\mathrm{X}_{1} \rightarrow \mathrm{Y}$ : Pengaruh model Team Assisted Individualization motivasi belajar

$\mathrm{X}_{2} \rightarrow$ Y: Pengaruh pengelolaan kelas terhadap motivasi belajar

$\mathrm{X}_{1} \mathrm{X}_{2} \rightarrow \mathrm{Y}$ :Pengaruh model Team Assisted Individualization (TAI), dan peengelolaan kelas secara bersamasama terhadap motivasi belajar.

Populasi adalah wilayah generalisasi yang terdiri atas objek/subjek yang mempunyai kualitas dan karakteristik tertentu yang ditetapkan oleh peneliti untuk dipelajari dan kemudian ditarik kesimpulan.Sesuai dengan masalah yang akan diteliti maka populasi dalam penelitian ini adalah seluruh peserta didik kelas VIII SMP Negeri 8 Makassar yang berjumlah 440 peserta didik. Sampel dalam penelitian ini penentuan jumlah sampel peneliti menggunakan tabel yang dikembangkan oleh Isaac dan Michael dengan taraf kesalahan 5\% didapatkan jumlah sampel sebanyak 195.Selanjutnya 195 peserta didik yang diambil dengan teknik simple random sampling pada setiap perwakilan kelas VIII SMP Negeri 8 Makassar.

Teknik pengumpulan data dalam penelitian ini adalah dokumentasi dan angket.Dokumentasi bisa berbentuk tulisan, gambar, atau karya-karya monumental dari seseorang. Dalam penelitian ini terdapat 3 angket yaitu: 1) angket model Team Assisted Individualization; 2) angket pengelolaan kelas; 3 ) angket motivasi belajar. Seluruh angket dikerjakan oleh peserta didik di SMP Negeri 8 Makassar.

Uji validitas dan reabilitas instrument dimaksudkan agar alat atau instrument yang digunakan dalam memperoleh data tepat dan konsisten. Untuk mengetahui butir pernyataan yang validdan reabilitas, uji coba angket 


\section{Syaifuddin, dkk. Pengaruh Model Pembelajaran Team Assisted Individualization ...}

penelitian perlu dilakukan sebelum angket digunakan sebagai instrument penelitian.

Data yang telah dikumpulkan, diolah dengan menggunakan dua macam teknik statistik yaitu teknik analisis statistik deskriptif dan teknik analisis statistik inferensial.

\section{Analisis Deskriptif}

Analisis deskriptif adalah statistik yang digunakan untuk menganalisis data dengan cara mendeskripsikan atau menggambarkan data yang terkumpul sebagaimana adanya tanpa bermaksud membuat kesimpulan yang berlaku untuk umum atau generalisasi. Pada penelitian yang akan dilaksanakan, statistik deskriptif akan disajikan dalam bentuk tabel kategori dan diagram dengan menganalisis nilai mean, median, modus, frekuensi, standar deviasi dan persentase.

2. Analisis Statistik Inferensial

Analisis statistik inferensial merupakan analisis yang menekankan pada hubungan antar variabel dengan menggunakan penyajian hipotesis dan menyimpulkan hasil penelitian. Sebelum pengujian hipotesis dilakukan, harus dilakukan uji persyaratan analisis terlebih dahulu untuk mengetahui normalitas dan linearitas data guna menentukan jenis statistik yang akan digunakan dalam pengujian hipotesis. Berikut ini penjabaran dari analisis statistik inferensial

1) Uji Persyaratan Analisis

Uji normalitas bertujuan untuk mengetahui apakah data yang terkumpul berdistribusi normal atau tidak. Dengan uji normalitas akan diketahui sampel yang diambil berasal dari populasi yang berdistribusi normal atau tidak. Apabila pengujian normal, maka hasil perhitungan statistik dapat digeneralisasikan pada populasinya. Uji normalitas dalam penelitian ini menggunakan bantuan program Statistical Package for Social Science (SPSS) versi 24. Dalam penelitian ini uji normalitas digunakan uji Kolmogorov-smirnov, kriterianya adalah signifikansi untuk uji dua sisi hasil perhitungan lebih besar dari 0,05 berarti berdistribusi normal.

2) Uji Linierias

Uji linearitas dilakukan untuk mengetahui linearitas hubungan antara variabel bebas dengan variabel terikat. Uji ini dilakukan dengan menggunakan bantuan program Statistical Package for Social Science (SPSS) versi 24yang dapat dilihat outputnya pada bagian ANOVA table yaitu hasil uji $\mathrm{F}$ untuk baris deviation from linearity. Jika nilai sig $\mathrm{F}$ tersebut kurang dari 0,05 maka hubungannya tidak linear, sedangkan jika nilai sig $\mathrm{F}$ lebih dari atau sama dengan 0,05 maka hubungannya bersifat linear.

3) Uji Multikoleniaritas

Uji multikoleniaritas digunakan untuk melihat ada tidaknya hubungan yang sangat kuat/sempurna antar variabel bebas (X). Uji ini dilakukan dengan menggunakan bantuan program Statistical Package for Social Science (SPSS) versi 24 dengan menggunakan uji VIF (Variance Inflation Factor). Pada uji VIP yang perlu dilihat adalah nilai VIF.Kriterianya adalah jika nilai VIF tersebut kurang dari 4 maka tidak terjadi multikolinearitas, sedangkan jika nilai VIF lebih dari 4 maka terjadi multikolinearitas.

4) Uji Hipotesis

Hipotesis yang diuji dalam penelitian ini adalah pengaruh variabel bebas model Team Assisted Individualization $\left(\mathrm{X}_{1}\right)$, dan pengelolaan kelas $\left(\mathrm{X}_{2}\right)$, terhadap variabel terikat motivasi belajar (Y) baik secara sendiri-sendiri maupun secara bersama-sama.

a) Regresi Sederhana

Uji regresi linier sederhana adalah hubungan secara linear antara satu variabel independen (X) dengan variabel dependen (Y).Analisis ini untuk mengetahui arah hubungan antara variabel independen dengan variabel dependen apakah positif atau negatif dan untuk memprediksi nilai dari variabel dependen apabila nilai variabel independen mengalami kenaikan atau penurunan.Data yang digunakan biasanya berskala interval atau rasio. Rumus regresi linear sederhana sebagai berikut:

$\mathrm{Y}^{\prime}=\mathrm{a}+\mathrm{bX}$

Keterangan:

$\mathrm{Y}^{\prime} \quad=$ Variabel dependen (nilai yang

diprediksikan)

$\mathrm{X}=$ Variabel independen

a $\quad=$ Konstanta (nilai $Y^{\prime}$ apabila $\mathrm{X}=0$ )

$\mathrm{b}=$ Koefisien regresi (nilai peningkatan ataupun penurunan).

(Sugiono 2018)

Dalam penelitian ini uji regresi linier sederhana menggunakan bantuan program Statistical Package for Social Science (SPSS) versi 24. Kriteria pengambilan keputusan, yaitu jika thitung $<$ tabel, maka Ho diterima, tapi jika thitung $>$ tabel, maka Ho ditolak dengan taraf signifikan $a=0,05$.

b) Uji Regresi Linier Berganda

Penelitian ini menggunakan variabel bebas, terdiri dari variabel model pembelajaran Team Assisted Individualization (TAI) dan 
variabel pengelolaan kelas, maka digunakan regresi linear berganda, yaitu analisis peramalan nilai pengaruh dua variabel bebas atau lebih terhadap variabel terikat untuk membuktikan ada atau tidaknya hubungan fungsi atau hubungan kausal antar dua variabel atau lebih. Manfaat dari hasil analisis regresi adalah untuk membuat keputusan apakah naik dan menurunnya variabel dependen dapat dilakukan melalui peningkatan variabel independen atau tidak. Secara konsepsional analisis regresi linear berganda mempunyai hubungan kausal dengan rumus sebagai berikut:

$\mathrm{Y}^{\prime}=\mathrm{a}+\mathrm{b}_{1} \mathrm{X}_{1}+\mathrm{b}_{2} \mathrm{X}_{2}$

Keterangan:

$\mathrm{Y}=$ variabel dependen (Motivasi belajar)

$\mathrm{a}=$ harga konstan (harga $\mathrm{Y}$ ketika harga $\mathrm{X}=0$ )

$\mathrm{b}=$ nilai-nilai variabel independen

$\mathrm{X} 1=$ variabel independen (Model TAI)

$\mathrm{X} 2=$ variabel independen (Pengelolaan kelas)

(Sugiono 2018).

Untuk pengujian hipotesis menggunakan bantuan Statistical Package for Social Science (SPSS) versi 24. Kriteria pengambilan keputusan yaitu jika Fhitung $<$ Ftabel, maka Ho diterima, tetapi jika Fhitung $>$ Ftabel, maka Ho ditolak dengan taraf signifikan $a=0,05$.

c) Uji Linier Multiple (Uji F)

Uji $\mathrm{F}$ bertujuan untuk menguji atau mengetahui pengaruh semua variabel independen terhadap variabel dependen, untuk mengetahui apakah variabel bebas secara bersama-sama memiliki pengaruh terhadap variabel terikat digunakan Uji F dengan rumus sebagai berikut:

$$
F_{h}=\frac{R^{2} / k}{\left(1-R^{2}\right) /(n-k-1)}
$$

Keterangan:

$\mathrm{R}$ : Koefisien korelasi ganda

$\mathrm{k}$ : Jumlah variabel independen

$\mathrm{n}$ : Jumlah anggota sampel

berikut :

Langkah - Langkah Pengujian sebagai

(1) Menentukan hipotesis

Ho :semua variabel independen (X) secara simultan tidak mempengaruhi variabel dependen (Y).

$\mathrm{Ha}$ :semua variabel independen (X) secara simultan mempengaruhi variabel dependen (Y).

(2) Menentukan derajat kepercayaan $95 \%(\alpha=$ $0,05)$

(3) Menentukan signifikansi

a) Nilai signifikansi $\leq 0,05$, maka Ho ditolak dan Ha diterima. b) Nilai signifikansi $>0,05$, maka Ho diterima dan Ha ditolak.

(4) Membuat Kesimpulan

a) Bila Fhitung memiliki nilai signifikansi $<$ 0,05, maka Ho ditolak dan Ha diterima, artinya seluruh variabel independen secara simultan mempengaruhi variabel dependen.

b) Bila Fhitung memiliki nilai signifikansi $>$ 0,05, maka Ho diterima dan Ha ditolak, artinya seluruh variabel independen secara simultan tidak mempengaruhi variabel dependen.

d) Koefisien Determinasi $\mathrm{R}^{2}$

Koefisien determinasi $\left(\mathrm{R}^{2}\right)$ pada intinya digunakan untuk mengukur seberapa jauh kemampuan model regresi dalam menerangkan variasi variabel dependen.Nilai $R^{2}$ yang kecil berarti kemampuan variabel-variabel independen dalam menjelaskan variabel dependen sangat terbatas.Nilai yang mendekati 1 berarti variabelvariabel independen memberikan hampir semua informasi yang dibutuhkan untuk memprediksi variabel dependen.

\section{HASIL DAN PEMBAHASAN}

Hasil penelitian pada bagian ini akan dijelaskan mengenai gambaran umum objek penelitian dan deskripsi responden. Selanjutnya data yang telah terkumpul dianalisis melalui dua tahap yaitu analisis deskritif dan analisis statistik.Berikut diuraikan hasil analisis deskriptif dari masing-masing sub variabel penelitian:

\section{Analisis Deskriptif Motivasi Belajat}

Data motivasi belajar didapat dengan menggunakan angket. Dimana peneliti membagikan angket kepada 195 peserta didik, dan angket tersebut memiliki 4 indikator yang terdiri dari 30 pernyataan, setiap pernyataan memiliki empat alternatif jawaban yang dipilih oleh peserta didik. Berdasarkan data penelitian yang diolah menggunakan bantuan komputer program IBM SPSS Statistic 24 untuk motivasi belajar skor terendah yang dicapai adalah 80 dan skor tertinggi adalah 120 dari data tersebut diperoleh harga rerata (mean) sebesar 102,59, nilai tengah (median) sebesar 103,00, modus (mode) sebesar 100, dan standar deviasi sebesar 9,718 . Pengkategorian pada variabel pengelolaan kelas dapat dilihat pada tabel 4.1

Tabel 4.1 Data Responden untuk Variabel Motivasi Belajar SMP Negeri 8 Makassar 
Syaifuddin, dkk. Pengaruh Model Pembelajaran Team Assisted Individualization ...

\begin{tabular}{lccc}
\hline \multicolumn{1}{c}{ Kategori } & $\begin{array}{c}\text { Rentan } \\
\text { g Skor }\end{array}$ & Frekuensi & $\begin{array}{c}\text { Frekuen } \\
\text { si (\%) }\end{array}$ \\
\hline Sangat Tinggi & $103-120$ & 111 & $56,92 \%$ \\
Tinggi & $85-102$ & 79 & $40,51 \%$ \\
Sedang & $67-84$ & 5 & $2,56 \%$ \\
Rendah & $49-66$ & 0 & $0 \%$ \\
Sangat Rendah & $31-48$ & 0 & $0 \%$ \\
\hline & Jumlah & $\mathbf{1 9 5}$ & $\mathbf{1 0 0 \%}$ \\
\hline
\end{tabular}

Sumber: Hasil Pengelolaan Data Penelitian.

Berdasarkan kategorisasi yang

dilakukan diketahui bahwa motivasi belajar masuk dalam kategori sangat tinggi sebanyak 111 peserta didik $(56,92 \%)$, tinggi sebanyak 79 peserta didik $(40,51 \%)$, sedang 5 peserta didik $(2,56 \%)$, rendah sebanyak $0(0 \%)$, dan sangat rendah $0(0 \%)$. Dari Presentase tersebut dapat disimpulkan bahwa pengelolaan kelas termasuk dalam kategori sangat tinggi.

\section{Hasil Analisis Deskriptif Model Team Assisted Individualization (TAI)}

Data model pembelajaran Team Assisted Individualization (TAI) didapat dengan menggunakan angket. Dimana peneliti membagikan angket kepada 195 peserta didik dan angket tersebut memiliki 7 indikator yang terdiri dari 30 pernyataan, setiap pernyataan memiliki empat alternatif jawaban yang dipilih oleh peserta didik. Berdasarkan data penelitian yang diolah menggunakan bantuan komputer program IBM SPSS Statistic 24 untuk model TAI skor terendah yang dicapai adalah 77 dan skor tertinggi adalah 119 dari data tersebut diperoleh harga rerata (mean) sebesar 96,46, nilai tengah (median) sebesar 97,00, modus (mode) sebesar 97, dan standar deviasi sebesar 7,615. Pengkategorian pada variabel model Team Assisted Individualization (TAI) dapat dilihat pada tabel 4.2

Tabel 4.2 Data Responden untuk Variabel Model TAI SMP Negeri 8 Makassar

\begin{tabular}{lccc}
\hline $\begin{array}{c}\text { Kategor } \\
\mathbf{i}\end{array}$ & $\begin{array}{c}\text { Rentan } \\
\text { g Skor }\end{array}$ & $\begin{array}{c}\text { Frekuens } \\
\mathbf{i}\end{array}$ & $\begin{array}{c}\text { Frekuens } \\
\mathbf{i}(\mathbf{\%})\end{array}$ \\
\hline $\begin{array}{l}\text { Sangat } \\
\text { Tinggi }\end{array}$ & $103-120$ & 39 & $20 \%$ \\
& $85-102$ & 153 & $78,46 \%$ \\
\hline
\end{tabular}

\begin{tabular}{lccc}
\hline Tinggi & $67-84$ & 3 & $1,53 \%$ \\
Sedang & $49-66$ & 0 & $0 \%$ \\
Rendah & $31-48$ & 0 & $0 \%$ \\
$\begin{array}{l}\text { Sangat } \\
\text { Rendah }\end{array}$ & 195 & $100 \%$ \\
\hline \multicolumn{3}{c}{ Jumlah } & \\
\hline $\begin{array}{l}\text { Sumber: Hasil Pengelolaan Data Penelitian. } \\
\text { Berdasarkan kategorisasi }\end{array}$ & yang
\end{tabular}
dilakukan diketahui bahwa model Team Assisted Individualization (TAI) masuk dalam kategori sangat tinggi sebanyak 39 peserta didik $(20 \%)$, tinggi sebanyak 153 peserta didik $(78,46 \%)$, sedang 3 peserta didik (1,53\%), rendah sebanyak $0 \quad(0 \%)$, dan sangat rendah $0 \quad(0 \%)$. Dari Presentase tersebut dapat disimpulkan bahwa model Team Assisted Individualization (TAI) termasuk dalam kategori tinggi.

\section{Hasil Analisis Deskriptif Pengelolaan Kelas}

Data pengelolaan kelas didapat dengan menggunakan angket.Dimana peneliti membagikan angket kepada 195 peserta didik.Dimana angket tersebut memiliki 5 indikator yang terdiri dari 30 pernyataan, setiap pernyataan memiliki empat alternatif jawaban yang dipilih oleh peserta didik. Berdasarkan data penelitian yang diolah menggunakan bantuan komputer program IBM SPSS Statistic 24 untuk pengelolaan kelas skor terendah yang dicapai adalah 78 dan skor tertinggi adalah 120 dari data tersebut diperoleh harga rerata (mean) sebesar 93,87, nilai tengah (median) sebesar 94,00, modus (mode) sebesar 94, dan standar deviasi sebesar 8,653. Pengkategorian pada variabel pengelolaan kelas dapat dilihat pada tabel 4.3 sebagai berikut:

Tabel 4.3 Data Responden untuk Variabel Pengelolaan Kelas SMP Negeri 8 Makassar

\begin{tabular}{lccc}
\hline \multicolumn{1}{c}{ Kategori } & $\begin{array}{c}\text { Rentan } \\
\text { g Skor }\end{array}$ & $\begin{array}{c}\text { Frekuens } \\
\mathbf{i}\end{array}$ & $\begin{array}{c}\text { Frekuens } \\
\mathbf{i}(\%)\end{array}$ \\
\hline Sangat Tinggi & $103-120$ & 40 & $20,51 \%$ \\
Tinggi & $85-102$ & 134 & $70,52 \%$ \\
Sedang & $67-84$ & 21 & $10,76 \%$ \\
Rendah & $49-66$ & 0 & $0 \%$ \\
\end{tabular}




\begin{tabular}{cccc}
\hline Sangat Rendah & $31-48$ & 0 & $0 \%$ \\
\hline & Jumlah & 195 & $100 \%$
\end{tabular}

Sumber: Hasil Pengelolaan Data Penelitian.

Berdasarkan kategorisasi yang

dilakukan diketahui bahwa pengelolaan kelas masuk dalam kategori sangat tinggi sebanyak 40 peserta didik (20,51\%), tinggi sebanyak 134 peserta didik $(70,52 \%)$, sedang 21 peserta didik $(10,76 \%)$, rendah sebanyak $0(0 \%)$, dan sangat rendah $0(0 \%)$. Dari Presentase tersebut dapat disimpulkan bahwa pengelolaan kelas termasuk dalam kategori tinggi.

\section{Uji Hipotesis}

a) Hipotesis Pertama

Hipotesis pertama yang diajukan dalam penelitian ini adala "Ada pengaruh yang positif dan signifikan model Team Assisted Individualization (TAI) dan pengelolaan kelas terhadap motivasi belajar PKKn peserta didik di SMP Negeri 8 Makassar". Untuk mengetahui pengaruh yang dimaksud dilakukan analisis korelasi dan regresi sederhana.Hasil analisis analisis korelasi dapat dilihat pada tabel 4.6.

Tabel 4.6 Hasil Uji Korelasi Model TAI dan Model Summary \begin{tabular}{l|l} 
Adjusted R & Std. Error of the
\end{tabular}

\begin{tabular}{|c|c|c|c|c|}
\hline del & $\mathrm{R}$ & R Square & Square & Estimate \\
\hline & $728^{\mathrm{a}}$ & .530 & 52 & 6,699 \\
\hline
\end{tabular}

a. Predictors: (Constant), Pengelolaan Kelas, Model TAI Pengelolaan Kelas Terhadap Motivasi

Sumber: IBM SPSS Statistic 24

Hasil perhitungan pada tabel 4.6 menunjukkan bahwa koefisien korelasi ganda sebesar 0,728 dan koefisien determinasi sebesar 0,530.Artinya terdapat korelasi yang signifikan antara model TAI dan pengelolaan kelas secara bersama-sama dengan motivasi belajar.

Berikutnya, untuk mengetahui bentuk hubungan model TAI (X1) dan pengelolaan kelas (X2) secara bersama-sama dengan motivasi belajar (Y), maka dapat dilihat pada tabel 4.7 sebagai berikut:

Tabel 4.7 Tabel Uji F

\begin{tabular}{lc|r|r|r|r}
\multicolumn{7}{c}{ ANOVA $^{\text {Sum of }}$} & \multicolumn{1}{c}{ Mean } & & \\
Model & Squares & Df & Square & F & Sig. \\
\hline Regression & 9703,748 & 2 & 4851,874 & 108,10 &, 00 \\
& & & & 4 & $0^{\text {b }}$ \\
\hline Residual & 8617,247 & 192 & 44,881 & & \\
\hline Total & 18320,995 & 194 & & & \\
\hline a. Dependent Variable: Motivasi Belajar \\
b. Predictors: (Constant), Pengelolaan Kelas, Model TAI \\
Sumber: IBM SPSS Statistic 24
\end{tabular}

Hasil analisis pada tabel 4.7 menunjukkan Fhitung sebesar 108,104 $>$ Ftabel 3,04 . Sementara tingkat signifikansi $0,000<0,05$ maka kedua indikator tersebut menunjukkan bahwa pengaruh model TAI dan pengelolaan kelas secara bersama-sama atau simultan adalah positif dan signifikan terhadap motivasi belajar.

Selanjutnya untuk menguji hubungan antara variabel model TAI (X1) dan Pengelolaan kelas (X2) benar-benar berpengaruh terhadap variabel motivasi belajar (Y) secara terpisah atau parsial dilakukan dengan uji $\mathrm{T}$, maka dapat dilihat pada tabel 4.8 sebagai berikut:

Tabel 4.8 Uji T Model TAI dan Pengelolaan Kelas Terhadap Motivasi Belajar

Sumber: IBM SPSS Statistic 24

Pada tabel 4.8 dapat dilihat variabel Coefficients $^{\mathrm{a}}$

Unstandardized Standardized

\begin{tabular}{|c|c|c|c|c|c|}
\hline \multirow[b]{2}{*}{ Model } & \multicolumn{2}{|c|}{$\begin{array}{l}\text { Unstandardized } \\
\text { Coefficients }\end{array}$} & \multirow{2}{*}{$\begin{array}{c}\text { Standardızed } \\
\text { Coefficients } \\
\text { Beta }\end{array}$} & \multirow[b]{2}{*}{$T$} & \multirow[b]{2}{*}{ Sig. } \\
\hline & B & Std. Error & & & \\
\hline (Constant) & 9,567 & 6,372 & & 1,501 & ,135 \\
\hline & ,587 & ,081 & & 7,249 & , 000 \\
\hline $\begin{array}{l}\text { engelolaan } \\
\text { elas }\end{array}$ & 388 & 071 & , 34! & 5,439 & , 000 \\
\hline
\end{tabular}

Kelas

a. Dependent Variable: Motivasi Belajar

model TAI (X1) memiliki thitung sebesar 7,249> ttabel 1,645 dengan signifikansi 0,000 berarti model TAI memiliki pengaruh positif dan

signifikan terhadap motivasi belajar.Variabel pengelolaan kelas (X2) memiliki thitung 5,439> tabel 1,645 dengan signifikansi 0,000 berarti pengelolaan kelas memiliki pengaruh yang positif dan signifikan terhadap motivasi belajar.

Dari hasil perhitungan diperoleh persamaan regresi model TAI dan pengelolaan kelas secara bersama-sama terhadap motivasi belajar dengan model regresinya 9,567 ditambah $0,587 \mathrm{X} 1+0,388 \mathrm{X} 2$. Daya prediksi model regresi yang ditemukan diatas ditentukan oleh koefisien sebesar 0,587 dan koefisien arah X2 sebesar 0,388 hal ini berarti bahwa setiap peningkatan model TAI (X1) sebesar 1 skala akan berkontribusi terhadap penambahan nilai motivasi belajar (Y) sebesar 0,587 skala dan peningkatan pengelolaan kelas (X2) sebesar 1 skala akan berkontribusi terhadap penambahan motivasi belajar (Y) sebesar 0,388 skala.

Dengan demikian hipotesis yang menyatakan bahwa "Ada pengaruh yang positif dan signifikan model Team Assisted Individualization (TAI) dan pengelolaan kelas terhadap motivasi belajar PPKn peserta didik di SMP Negeri 8 Makassar" dapat diterima dan telah teruji secara empiris pada taraf kepercayaan 95\% hal ini berarti bahwa model regresi ganda 


\section{Syaifuddin, dkk. Pengaruh Model Pembelajaran Team Assisted Individualization ...}

yang ditemukan dapat digunakan untuk meramalkan motivasi belajar PPKn di SMP Negeri 8 Makassar, bila skor model TAI dan pengelolaan kelas diketahui besar kontribusinya adalah 0,530 atau $53 \%$. Artinya motivasi belajar dapat dijelaskan oleh variasi model TAI dan pengelolaan kelas. Sedangkan sisanya $47 \%$ dapat dijelaskan oleh faktor lain yang tidak termasuk dalam penelitian ini. Misalnya kedisiplinan belajar, lingkungan belajar, pola asuh orang tua, minat belajar, media pembelajaran, dan lain sebagainya.

\section{b) Hipotesis Kedua}

Hipotesis kedua yang diajukan dalam penelitian ini adala "ada pengaruh yang positif dan signifikan model Team Assisted Individualization (TAI) terhadap motivasi belajar PPKn peserta didik di SMP Negeri 8 Makassar". Untuk mengetahui pengaruh yang dimaksud dilakukan analisis korelasi dan regresi sederhana.Hasil analisis korelasi dapat dilihat pada tabel 4.9 sebagai berikut:

Tabel 4.9 Uji Korelasi Model TAI Terhadap Motivasi Belajar

\begin{tabular}{l|c|c|r|r} 
& & \multicolumn{3}{c}{ Model Summary } \\
Model & $\mathrm{R}$ & $\mathrm{R}$ Square & $\begin{array}{c}\text { Adjusted R } \\
\text { Square }\end{array}$ & $\begin{array}{c}\text { Std. Error of } \\
\text { the Estimate }\end{array}$ \\
\hline 1 &, $676^{\mathrm{a}}$ &, 457 &, 454 & 7,178 \\
\hline a. Predictors: (Constant), Model TAl & & \\
Sumber: IBM SPSS Statistic 24 &
\end{tabular}

Hasil perhitungan pada tabel 4.9 menunjukkan bahwa koefisien antara model TAI dengan motivasi belajar adalah positif. Hal ini dapat dilihat pada koefisen korelasinya sebesar 0,676.Berdasarkan hasil perhitungan dapat dijelaskan bahwa model TAI berkorelasi dengan motivasi belajar dengan bentuk hubungan yang positif dengan koefisien determinasi 0,457.

Berikutnya, untuk mengetahui bentuk hubungan model TAI (X1) dengan motivasi (Y), apakah hubungan itu berpengaruh atau tidak,maka dapat dilihat pada tabel 4.10 sebagai berikut:

Tabel 4.10 Hasil Uji Regresi Sederhana Model TAI Terhadap Motivasi Belajar

\begin{tabular}{|c|c|c|c|c|c|}
\hline \multirow[b]{3}{*}{ Model } & \multicolumn{3}{|c|}{ Coefficients $^{a}$} & \multirow[b]{3}{*}{$\mathrm{T}$} & \multirow[b]{3}{*}{ Sig. } \\
\hline & \multicolumn{2}{|c|}{$\begin{array}{l}\text { Unstandardized } \\
\text { Coefficients }\end{array}$} & \multirow{2}{*}{$\begin{array}{c}\text { Standardize } \\
d \\
\text { Coefficients } \\
\text { Beta }\end{array}$} & & \\
\hline & B & $\begin{array}{l}\text { Std. } \\
\text { Error }\end{array}$ & & & \\
\hline 1 (Constant) & 19,357 & 6,549 & & $\begin{array}{r}2,95 \\
6\end{array}$ &, 004 \\
\hline Model TAI & 863 & ,068 & ,676 & $\begin{array}{r}12,7 \\
49\end{array}$ & ,000 \\
\hline
\end{tabular}

a. Dependent Variable: Motivasi Belajar
Sumber: IBM SPSS Statistic 24

Hasil analisis pada tabel 4.10 diperoleh persamaan regresi sebagai berikut $\mathrm{Y}=19,357+$ $0,863 \mathrm{X} 1$. Daya prediksi model regresi yang ditemukan diatas ditentukan oleh koefisien arah sebesar 0,863 .

Hasil analisis juga menunjukkan variabel model TAI (X1) memiliki thitung 12, 749 $>$ ttabel 1,645 dengan signifikansi $0,000<0,05$ berarti model TAI memiliki pengaruh positif dan signifikan terhadap motivasi belajar.

Analisis diatas memperlihatkan bahwa hipotesis penelitian yang menyatakan model TAI berpengaruh positif dan signifikan terhadap motivasi belajar dapat diterima dan telah diuji kebenarannya. Secara empiris pada taraf kepercayaan 95\%.Selanjutnya dapat diinterpretasikan bahwa faktor model TAI berpengaruh secara positif dan signifikan terhadap motivasi belajar. Pengaruh model TAI terhadap motivasi belajar PPKn di SMP Negeri 8 Makassar sebesar 0,457 atau 45,7\%. Sedangkan sisanya $53 \%$ dipengrahui oleh variabel lain yang tidak diteliti dalam penelitian ini.

c) Hipotesis Ketiga

Hipotesis ketiga yang diajukan dalam penelitian ini adalah "Ada pengaruh yang positif dan signifikan pengelolaan kelas terhadap motivasi belajar PPKn peserta didik di SMP Negeri 8 Kota Makassar". Untuk mengetahui pengaruh yang dimaksud dilakukan analisis korelasi dan regresi sederhana. Hasil analisis analisis korelasi dapat dilihat pada tabel 4.12sebagai berikut:

Tabel 4.12 Hasil Uji Korelasi Pengelolaan Kelas Terhadap Motivasi Belajar

\begin{tabular}{|c|c|c|c|c|}
\hline \multicolumn{5}{|c|}{ Model Summary } \\
\hline $\begin{array}{l}\text { Mode } \\
\text { I }\end{array}$ & $\mathrm{R}$ & R Square & $\begin{array}{l}\text { Adjusted R } \\
\text { Square }\end{array}$ & $\begin{array}{l}\text { Std. Error of } \\
\text { the Estimate }\end{array}$ \\
\hline 1 &, $633^{a}$ & ,401 & ,398 & 7,541 \\
\hline
\end{tabular}

Hasil perhitungan pada tabel 4.12 menunjukkan bahwa koefisien antara pengelolaan kelas dengan motivasi belajar adalah positif.Hal ini dapat dilihat pada koefisen korelasinya sebesar 0,633.Berdasarkan hasil perhitungan dapat dijelaskan bahwa model TAI berkorelasi dengan motivasi belajar dengan bentuk hubungan yang positif dengan koefisien determinasi 0,401.

Berikutnya, untuk mengetahui bentuk hubungan pengelolaan kelas (X2) dengan motivasi belajar (Y), apakah hubungan itu 
berpengaruh atau tidak, maka dapat dilihat pada tabel 4.13 sebagai berikut:

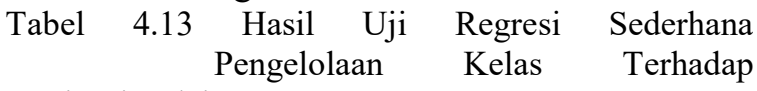

Motivasi Belajar

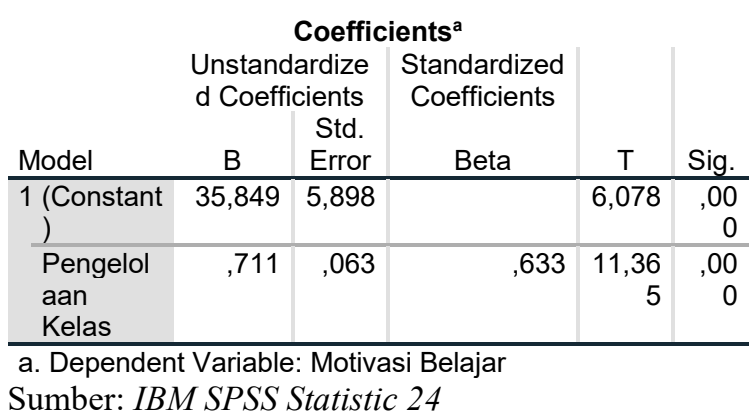

Hasil analisis pada tabel 4.13 diperoleh persamaan regresi sebagai berikut $\mathrm{Y}=35,849+$ $0,711 \mathrm{X} 2$. Daya prediksi model regresi yang ditemukan diatas ditentukan oleh koefisien arah sebesar 0,711 . Hal ini menunjukkan bahwa setiap peningkatan pengelolaan kelas sebesar 1 skala akan berkontribusi terhadap peningkatan motivasi belajar sebesar 0,711 skala.

Hasil analisis juga menunjukkan variabel pengelolaan kelas (X2) memiliki thitung $11,365>$ ttabel 1,645 dengan signifikansi $0,000<$ 0,05 berarti pengelolaan kelas memiliki pengaruh positif dan signifikan terhadap motivasi belajar.

Analisis diatas memperlihatkan bahwa hipotesis penelitian yang menyatakan pengelolaan kelas berpengaruh positif dan signifikan terhadap motivasi belajar dapat diterima dan telah diuji kebenarannya. Secara empiris pada taraf kepercayaan $95 \%$.Selanjutnya dapat diinterpretasikan bahwa faktor pengelolaan kelas berpengaruh secara positif dan signifikan terhadap motivasi belajar. Pengaruh pengelolaan kelas terhadap motivasi belajar PPKn di SMP Negeri 8 Makassar sebesar 0,401 atau $40,1 \%$. Sedangkan sisanya $59,9 \%$ dipengrahui oleh variabel lain yang tidak diteliti dalam penelitian ini.

\section{Pembahasan}

\section{Pengaruh Model TAI dan Pengelolaan Kelas Terhadap Motivasi Belajar PPKn Peserta didik SMP Negeri 8 Makassar}

Hasil penelitian menunjukkan bahwa besar pengaruh antara model pembelajaran Team Assisted Individualization (TAI) dan pengelolaan kelas secara simultan terhadap motivasi belajar PPKn peserta didik yang dihitung dengan koefisien determinasi sebesar 0.530 . Hal tersebut menunjukkan terdapat pengaruh yang positif.
Dari hasil analisis data diketahui besar konstribusi model Team Assisted Individualization (TAI) dan pengelolaan kelas adalah 0,530 atau $53 \%$. Artinya motivasi belajar dapat dijelaskan oleh variasi model TAI dan pengelolaan kelas. Sedangkan sisanya $47 \%$ dapat dijelaskan oleh faktor lain yang tidak termasuk dalam penelitian ini.

Model Team Assisted Individualization (TAI) merupakan salah satu model pembelajaran kooperatif yang dapat membangkitkan motivasi belajar peserta didik, karena dalam sintaksnya terdapat pemberian penghargaan atas hasil kerja peserta didik. Dari hasil penelitian juga menunjukkan siswa sangat antusias ketika guru PPKn menerapkan model Team Assisted Individualization (TAI) pada saat pembelajaran di kelas.

Selain variabel model Team Assisted Individualization (TAI), variabel pengelolaan kelas juga memberikan pengaruh motivasi belajar kepada peserta didik. Dengan pengelolaan kelas yang dilakukan oleh guru sehingga terciptanya kelas yang kondusif, efektif dan efisien karena pada dasarnya proses pendidikan yang dilaksanakan disekolah didominasi oleh kegiatan belajar mengajar. Kegiatan pengelolaan kelas yang dilakukan oleh guru PPKn seperti manajemen kelas, manajemen siswa, manajemen kegiatan pembelajaran, manajemen isi (materi pembelajaran), manajemen sumber belajar membuat peserta didik menjadi antusias dalam proses pembelajaran.

Berdasarkan uraian di atas maka dapat disimpulkan bahwa terdapat pengaruh yang positif dan signifikan antara model pembelajaran Team Assisted Individualization (TAI) dan pengelolaan kelas terhadap motivasi belajar peserta didik di SMP Negeri 8 Makassar.

\section{Pengaruh Model TAI Terhadap Motivasi Belajar PPKn Peserta didik SMP Negeri 8 Kota Makassar}

Hasil penelitian menunjukkan bahwa terdapat pengaruh yang positif dan signifikan antara model Team Assested Individualization (TAI) terhadap motivasi belajar PPKn peserta didik di SMP Negeri 8 Makassar. Hal tersebut dibuktikan dari hasil analisis regresi diperoleh nilai sebesar 0,863 .

Hasil analisis juga menunjukkan variabel model TAI (X1) memiliki thitung 12, 749 $>$ ttabel 1,645 dengan signifikansi $0,000<0,05$, sehingga dapat disimpulkan bahwa hipotesis 
pertama (Ha) diterima yang berarti berarti model TAI memiliki pengaruh positif terhadap motivasi belajar PPKn Peserta Didik SMP Negeri 8 Makassar. Dari penjelasan tersebut dapat disimpulkan bahwa variabel model Team Assested Individualization (TAI) terhadap motivasi belajar mempunyai pengaruh positif dan signifikan. Dengan demikian dapat dikatan bahwa jika semakin tinggi model Team Assested Individualization (TAI), maka motivasi belajar PPKn akan semakin tinggi pula.

\section{Pengaruh Pengelolaan Kelas Terhadap Motivasi Belajar PPKn Peserta didik SMP Negeri Makassar}

Hasil penelitian menunjukkan bahwa terdapat pengaruh yang positif dan signifikan antara pengelolaan kelas terhadap motivasi belajar PPKn peserta didik di SMP Negeri 8 Makassar.Hal tersebut dibuktikan dari hasil analisis regresi diperoleh angka sebesar 0,711.

Hasil penelitian juga menunjukkan variabel pengelolaan kelas (X2) memiliki thitung $11,365>$ ttabel 1,645 dengan signifikansi $0,000<$ 0,05 hal ini menunjukkan bahwa pengelolaan kelas memiliki pengaruh positif dan signifikan terhadap motivasi belajar. Hal ini berarti hipotesis kedua diterima.

Hasil penelitian ini konsisten dengan teori yang dikemukakan oleh Djabidi (2016) yang menjelaskan bahwa pengelolaan kelas dimaksudkan sebagai proses menciptakan dan mempertahankan suasana kelas agar kegiatan mengajar dapat berlangsung secara sistematis, efektif dan efisien sehingga segala potensi peserta didik mampu dioptimalkan.

\section{SIMPULAN DAN SARAN}

\section{Kesimpulan}

Berdasarkan hasil pengujian hipotesis dan pembahasan yang telah dilakukan, maka kesimpulan yang dihasilkan pada penelitian ini adalah sebagai berikut:

1. Terdapat pengaruh yang positif dan signifikan model Team Assisted ndividualization (TAI) dan pengelolaan kelas terhadap motivasi belajar PPKn peserta didik di SMP Negeri 8 Makassar. Ditunjukkan dengan nilai Fhitung sebesar $108,104>$ Ftabel 3,04. Sementara tingkat signifikansi $0,000<0,05$ dan koefisien determinasi sebesar 0,530 yang berarti secara simultan ada $53 \%$ pengaruh model TAI dan pengelolaan kelas terhadap motivasi belajar PPKn peserta didik di SMP Negeri 8 Makassar.

2. Terdapat pengaruh yang positif dan signifikan antara model pembelajaran Team Assisted Individualization (TAI) terhadap motivasi belajar PPKn peserta didik di SMP Negeri 8 Makassar. Ditunjukkan dengan nilai thitung $12,749>$ tabel 1,645 dengan signifikansi $0,000<0,05$ dan koefisien determinasi sebesar 0,457 yang berarti secara parsial ada $47 \%$ pengaruh model TAI terhadap motivasi belajar PPKn di SMP Negeri 8 Makassar.

3. Terdapat pengaruh yang positif dan signifikan antara pengelolaan kelas terhadap motivasi belajar PPKn peserta didik di SMP Negeri 8 Makassar. Ditunjukkan nilai thitung $11,365>$ tabel 1,645 dengan signifikansi $0,000<0,05$ dan koefisien determinasi sebesar 0,401 yang berarti secara parsial ada $40,1 \%$ pengaruh pengelolaan kelas terhadap motivasi belajar PPKn di SMP Negeri 8 Makassar.

\section{Saran}

Saran yang dapat penulis sampaikan adalah: (1) Melalui model Team Assisted Individualization (TAI) ini sebagai solusi bagi guru untuk meningkatkan motivasi belajar PPKn peserta didik di SMP dan juga dapat diterapkan pada mata pelajaran lain, (2) Pengelolaan kelas sangat perlu dilakukan oleh guru untuk menciptkan pembelajaran yang efektif dan efisien, (3) Sekolah secara rutin melaksanakan pengawasan dalam pelaksanaan pembelajaran, sehingga tercapai kegiatan belajar mengajar yang menjadikan peserta didik memiliki minat yang tinggi dalam rangka meningkatkan motivasi belajar PPKn peserta didik, dan (4) Saran bagi peneliti selanjutnya. Penelitian ini memberikan informasi bahwa bukan hanya variable model pembelajaran Team Assisted Individualization (TAI) dan pengelolaan kelas yang dapat mempengaruhi motivasi belajar PPKn peserta didik, akan tetapi masih banyak variabel-variabel yang lain. 


\section{DAFTAR RUJUKAN}

Bakri, Noor Ms. 2012. Pendidikan Kewarganegaraan. Yogyakarta: Pustaka Pelajar Offset.

Dimyanti dan Mudjino. 2006. Belajar dan Pembelajaran. Jakarta: PT Rineka Cipta.

Djabidi, Faizal.. 2016. Manajemen Pengelolaan Kelas. Malang: Madani.

Emda, Amma. 2017. Kedudukan Motivasi Belajar Siswa Dalam Pembelajaran. Lantanida Journal. Vol.5.no.2. (https://jurnal.ar-raniry.ac.id/).Diakses 25 Desember 2019).

Fathurrohman dan Wuryandani, Wuri. 2011. Pembelajaran PKn di Sekolah. Yagyakarta: Nuha Litera.

Sardiman. 2014. Interaksi dan Motivasi Belajar Mengajar. Jakarta: PT Raja Grafindo Persada.

Syardiansah. 2016. Hubungan Motivasi Belajar dan Minat Belajar terhadap Prestasi Belajar Mahasiswa Mata Kuliah Pengantar Manajemen (Studi kasus Mahasiswa Tingkat I EKM A Semester II). Jurnal Manajemen Dan Keuangan. Vol. 5.No. 1. (https://ejurnal unsam.id/ind/, Diakses 23 Desember 2019).

Shoimin, Aris. 2014. 68 Model Pembelajaran Inovatif dalam Kurikulum 2013. Yogyakarta: Ar-Ruzz Media.

Slavin, Robert E. 2005.Cooperatif Learning Teori Riset dan Praktik.Bandung: Nusa Media.

Sutrisno.2017. Implementasi Pendidikan Antikorupsi pada Mata Pelajaran PPKn Berbasis Project citizen di SMA.Jurnal Civics. Vol.14.no.2. Jurnal Civics.Vol. 14.No.

(https://journal.uny.ac.id/index.php/civis L, Diakses 10 Oktober 2019).

Sugiyono, 2018.Metode Penelitian Kuantitatif..Bandung: Alfabeta.

Tim Redaksi Laksana, 2019. Himpunan Lengkap Undang-Undang Republik Indonesia Tentang Sistem Pendidikan Nasional (SISDIKNAS) dan Standar Nasional
Pendidikan. Yogyakarta: Laksana.

Wena, Made. 2009. Strategi Pembelajaran Inovatif Kontemporer. Jakarta: Bumi Aksara.

Yusuf, Syamsu. 2009. Program Bimbingan dan Konseling di Sekolah. Bandung: Rizqi Perss. 